\title{
Microhabitat selection of a Sicilian subterranean woodlouse and its implications for cave management
}

\author{
Giuseppe Nicolosi (D) ${ }^{1}$, Stefano Mammola (D) ${ }^{2,3}$, Salvatore Costanzo (D) ${ }^{4}$, Giorgio Sabella (D) ${ }^{5}$, \\ Rosolino Cirrincione (D) ${ }^{5}$, Giovanni Signorello (D) ${ }^{6}$, and Marco Isaia (D) ${ }^{{ }^{*}}$ \\ ${ }^{1}$ Department of Life Sciences and Systems Biology, University of Turin, Via Verdi 8 - 10124, Torino, Italy \\ ${ }^{2}$ Laboratory for Integrative Biodiversity Research (LIBRe), Finnish Museum of Natural History (Luomus), University of Helsinki, \\ Pohjoinen Rautatiekatu 13, 00100 Helsinki, Finland \\ ${ }^{3}$ Molecular Ecology Group (MEG), Water Research Institute, National Research Council of Italy (CNR-IRSA), Largo Tonolli 50, \\ 28922 Verbania Pallanza, Italy \\ ${ }^{4}$ Centro Universitario per la Tutela e la Gestione degli Ambienti Naturali e degli Agroecosistemi, University of Catania, \\ Piazza Università, 2 - 95131 Catania, Italy \\ ${ }^{5}$ Department of Biological, Geological and Environmental Sciences, University of Catania, Piazza Università, 2 - 95131 Catania, Italy \\ ${ }^{6}$ Department of Agriculture, Food and Environment, University of Catania, Piazza Università, 2 - 95131 Catania, Italy
}

\begin{abstract}
Human activities in subterranean environments can affect different ecosystem components, including the resident fauna. Subterranean terrestrial invertebrates are particularly sensitive to environmental change, especially microclimatic variations. For instance, microclimate modifications caused by the visitors may directly affect local fauna in caves opened to the public. However, since numerous factors act synergistically in modulating the distribution and abundance of subterranean species, it remains challenging to differentiate the impact of human intervention from that of other factors. Therefore, evidence of the impact of tourism on cave invertebrate fauna remains scarce. Over a year and with approximately two visits a month, we investigated the effects of the presence of visitors on the subterranean endemic woodlouse Armadillidium lagrecai in the strict natural reserve of Monello Cave (Sicily, Italy). We found that natural microclimatic fluctuations, and not direct human disturbance, were the main factors driving the distribution of $A$. lagrecai. Specifically, $A$. lagrecai select for more climatically stable areas of the cave, where the temperature was constantly warm and the relative humidity close to saturation. We also observed a significant temporal effect, with a greater abundance of $A$. lagrecai in summer and a gradual decrease during the winter months. The number of visitors in the Monello cave had no effect on the abundance and distribution of $A$. lagrecai. However, considering the high sensitivity of the species to microclimatic variations, it seems likely that a significant increase in the number of visitors to the cave could indirectly affect this species by altering local microclimate. Constant monitoring of the environmental parameters within the cave is therefore recommended.
\end{abstract}

Keywords: Armadillidium, biodiversity conservation, cave arthropods, human impacts, subterranean fauna Received 25 November 2020; Revised 3 March 2021; Accepted 3 March 2021

Citation: Nicolosi G., Mammola S., Costanzo S., Sabella G., Cirrincione R., Signorello G. and Isaia M., 2021. Microhabitat selection of a Sicilian subterranean woodlouse and its implications for cave management. International Journal of Speleology, 50 (1), 53-63. Tampa, FL (USA) ISSN 0392-6672 https://doi.org/10.5038/1827-806X.50.1.2370

\section{INTRODUCTION}

Subterranean ecosystems are highly stable relative to their surrounding surface environments (Poulson $\&$ White, 1969; Howarth, 1980; 1993). The permanent darkness, scarce energy inputs, constantly high relative humidity, and temperature stability exert a selective pressures driving the evolution of specific physiological, morphological, and behavioral traits on resident organisms (Culver \& Pipan, 2010). Consequently, subterranean species often show pronounced sensitivity to even small changes in the environmental conditions (e.g., Barr \& Kuehne, 1971; Howarth, 1980; Culver, 2005). Temperature is one of the major abiotic factors affecting subterranean species and their life history (Bernabò et al., 2011; Novak et al., 2014; Rizzo et al., 2015; Mammola et al., 2019b; Pallarés et al., 2019, 2020); most specialized subterranean species select microhabitats where the temperature is generally higher and stable, such as the innermost areas of caves. The presence of subterranean fauna is similarly correlated with stable and high relative humidity, as their thin cuticles of cave adapted organisms render them vulnerable 
to desiccation (Howarth, 1980) which they would encounter in the drier areas of the cave.

Owing to this sensitivity of the specialized subterranean fauna, there is nowadays a growing awareness of a need for protection of subterranean ecosystems (Mammola et al., 2019a).

As fragile and confined environments, cave ecosystems are susceptible to numerous impacts related to human activities (Culver \& Pipan 2019; Romero, 2009). One of the most studied among these impacts is the effect of touristic activities in caves opened to visitors (Cigna, 2016). Human-induced impacts associated to tourist caves can affect different ecosystem components (Mammola, 2019), but our understanding of the nuances of these effects remains scarce (Mammola et al., 2020). A massive presence of tourist directly alters the underground microclimate resulting in seasonal variations in temperature and relative humidity (Cigna, 2004). At the same time, the joint effect of visitors and artificial lights affects the presence of microorganism and their distribution (Mulec, 2014). For example, organic materials passively transferred into the caves by visitors may enhance the growth of bacterial and fungal species alien to the cave community (Chelius et al., 2009; Mammola et al., 2017; Pfendler et al., 2018), whereas artificial lights lead to the development of photosynthetic biofilms (lampenflora) on rocky surfaces (Falasco et al., 2014; Piano et al., 2015; Baquedano Estévez et al., 2019). While an influence of tourism on the resident terrestrial fauna could also be expected, evidence related to the impact of direct anthropic disturbance on cave dwelling arthropods remains scarce (Isaia et al., 2011; Pellegrini \& Ferreira, 2012; Pacheco et al., 2020).

Being specialized animals, subterranean invertebrates are theoretically vulnerable even to minor changes in their environment, including human-induced alterations. For instance, trampling of visitors and the subsequent modification to the substrate might cause a direct disturbance (Spate $\&$ Hamilton-Smith, 1991). The growth of lampenflora as well as the introduction of external opportunistic species of microbes favor the proliferation of more competitive species, which threaten the local cavedwelling fauna (Mulec et al., 2008; Mulec \& Kosi, 2009; Castello, 2014). Also, microclimate modifications associated with tourism could potentially cause the disappearance or migration of the local fauna (Slaney \& Weinstein, 1997; Juberthie, 2000; Krajick, 2001; van Beynen \& Townsend, 2005). A greater knowledge of the cave's main physical parameters inside the cave (in particular temperature, humidity, and $\mathrm{CO}_{2}$ ) is essential for the conservation of the cave environment and its fauna. Moreover, is necessary to distinguish if environmental changes are due to natural causes or human activities in order to possibly define criteria for their conservation (Huppert et al., 1993; FernandezCortes et al., 2006). However, due to the lack of long time series of data and several sampling impediments, it is generally difficult to tease apart the influence of these two factors in driving diversity patterns in caves (Eberhard, 2001).
The aim of our study was to explore the relative influence of microclimatic variations and the presence of visitors on the spatio-temporal dynamics of specialized subterranean fauna. We used the Monello Cave as a model system. It is located in a Strict Natural Reserve in eastern Sicily, and is renowned for its peculiar subterranean terrestrial fauna (Caruso, 1994). In particular, we focused on the specialized subterranean woodlouse Armadillidium lagrecai Vandel, 1969 (Malacostraca: Isopoda: Armadillidiidae) and its relation to both natural and anthropogenic factors related to cave tourism.

\section{MATERIAL AND METHODS}

\section{Study area}

The Monello Cave (cadastral number SiSr7007, Latitude $37^{\circ} 01^{\prime} 04.00^{\prime \prime} \mathrm{N}$; Longitude $15^{\circ} 09^{\prime} 57^{\prime \prime} \mathrm{E}$, altitude $10 \mathrm{~m}$ ) is located in the municipality of Siracusa, in southeastern Sicily (Italy). The cave is included in the Strict Nature Reserve "Grotta Monello" (Fig. 1). The reserve was established in 1998 in order to protect the cave, its speleothems and its invertebrate fauna (see Caruso, 1994; Nicolosi et al., 2019; Sendra et al., 2019; Sabella et al., 2020). The cave is also part of the Special Area of Conservation (SAC) ITA090011 "Grotta Monello" and is formally recognized as a Geosite of regional interest. The site is managed by the Centro Universitario per la Tutela e la Gestione degli Ambienti Naturali e degli Agroecosistemi of the University of Catania (CUTGANA).

The cave is located in the eastern sector of the Hyblean Plateau, within the NW-SE trending Late Quaternary Floridia Basin (Ghisetti \& Vezzani, 1980), a $12 \mathrm{~km}$ wide and $20 \mathrm{~km}$ long tectonic depression characterizing the northeastern sector of the Hyblean Plateau. It is located in the Early-Middle Miocene calcarenites and calcirudites with fragments of bryozoa, echinoderms, algae, and bivalves that constitute the upper member (or Siracusa Member) of the Climiti Mounts Formation (Pedley, 1981).

The cave has a total planimetric development of about $540 \mathrm{~m}$. The first part consists of an artificially excavated horizontal gallery, $110 \mathrm{~m}$ in length, accessible through a small iron gate that prevents any unauthorized access to the cave. The gallery leads to the main room of the cave ("Sala Grande"). From there, several secondary passages originate, developing along different levels and showing a remarkable concentration of speleothems.

The cave was heavily modified to make it accessible for tourism. In the $80 \mathrm{~s}$, the Province of Siracusa excavated a pathway across the cave, which destroyed a huge number of speleothems (Fig. 2a).

Before the official opening, a study conducted by the University of Catania led to the discovery of an invertebrate assemblage of considerable interest (Caruso, 1994). This assemblage included specialized subterranean species such as the diplopod Glomeris dionysii (Strasser 1961) (Diplopoda: Glomerida: Glomeridae) and the isopod Armadillidium lagrecai (Fig. 2b), so far uniquely found in the Monello Cave. The peculiarity of the local fauna prompted the 


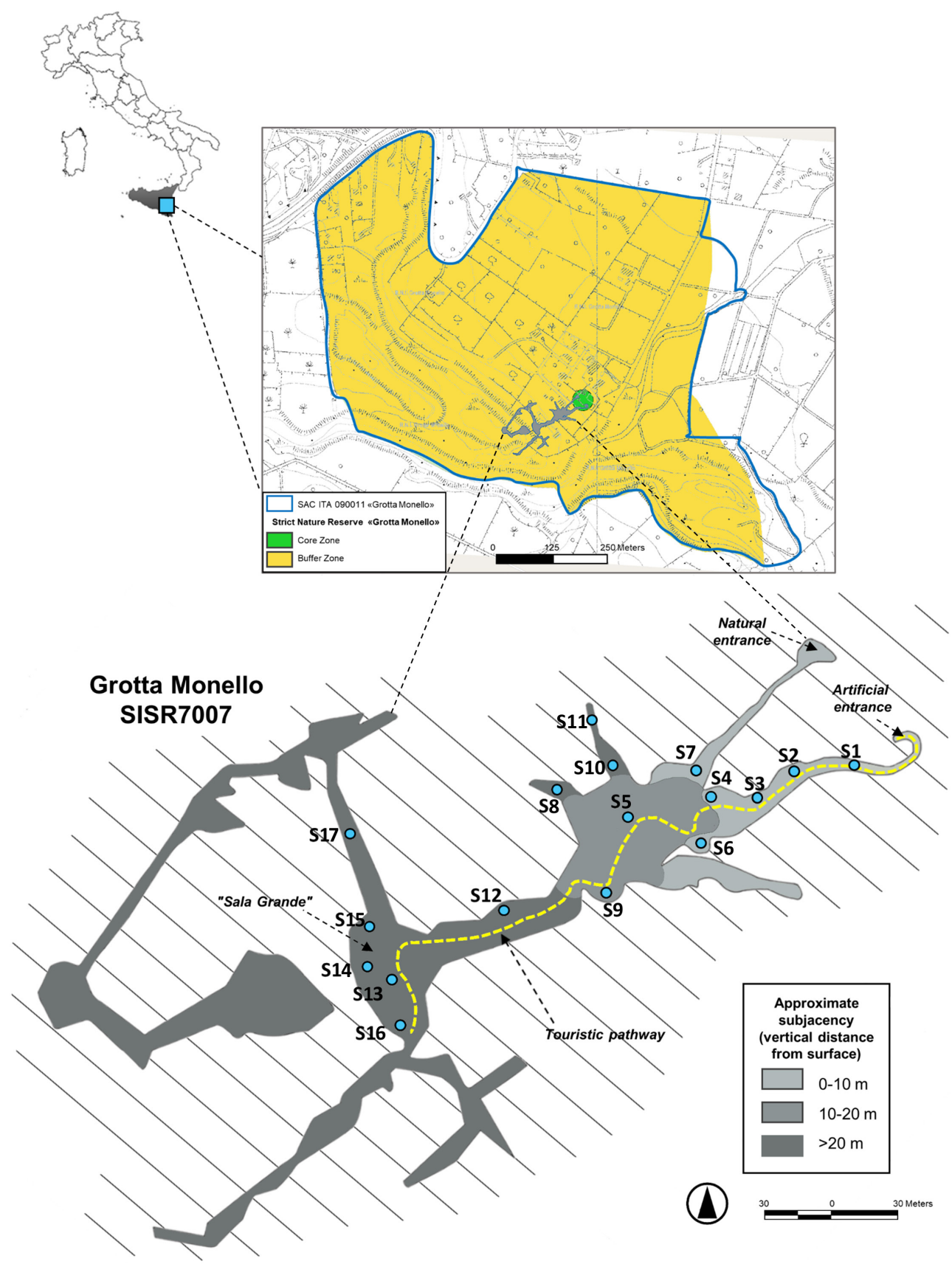

Fig. 1. Map of the study area. The sampling sites are represented by blue dots, located at $16,24,43$, $47,52,62,63,73,83,84,92,96,120,123,131,136$, and $143 \mathrm{~m}$ from the cave entrance. The different grey shades represent the subjacency (i.e., vertical distance from the surface).Topography of the Monello Cave is from the original drawings of Ruggieri \& Amore (2000).

establishment of the Strict Nature Reserve, preventing uncontrolled touristic use.

\section{Management of the Monello Cave}

From its establishment in 1988 until 2018, access to the Monello Cave had been regulated by the managing body (CUTGANA) and its usage limited to approved scientific research.

Starting in 2018 , the cave was opened to the public for a scientific investigation to evaluate the impact of visitors on the subterranean ecosystem. As of 2020, visitors were allowed in the cave under strict regulation: 3 visits were permitted per month and each visitor group was limited to twenty-four people, which in turn were divided in two subgroups of twelve, excluding one guide and one assistant. Visitors were not allowed to spend more than 40 minutes inside the cave, and each wore a helmet with a flashlight dimmer than 100 lumens. There was no built-in lighting system and visitors were required to stay on the visitor path.

\section{Sampling design}

We conducted the study from December 2018 to February 2020. We visited the cave 27 times over 14 months (approximately two visits/month).

Based on previous studies (Faille et al., 2014, Piano et al., 2015, Mammola et al., 2017), we considered the number of visitors and the distance from the tourist path as proxies for the human disturbance. We assumed these to be the only perturbations currently present in the Monello cave that are potentially capable of causing a measurable impact. In particular, we assigned to each sampling event the total number of visitors to the cave in the previous two weeks. In this regard, we selected nine sampling points along the visitor pathway (sampling points number 1, 2, 4, 

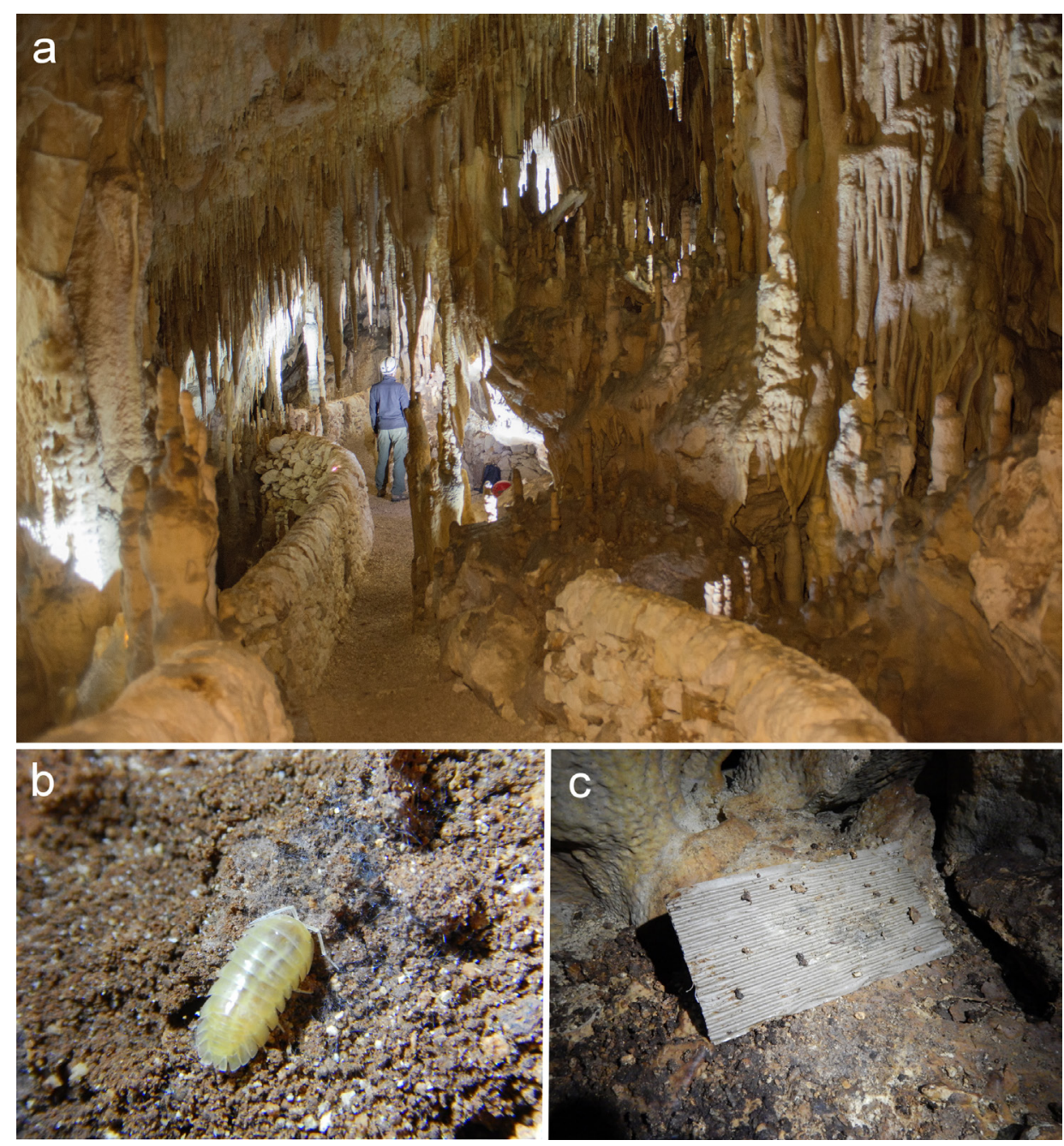

Fig. 2. a) The corridor leading to the "Sala Grande" in the Monello Cave; b) The subterranean woodlouse Armadillidium lagrecai Vandel 1969; c) The cardboard used for sampling the fauna in the Monello Cave.

$7,9,12,13,14$, and 16), and eight further points away from the path and/or in the lateral branches not opened to public (sampling points number 3, 6, $5,8,10,11,15$, and 17, see Fig. 1). We measured the distance from the cave entrance and from the pathway with a Leica DISTO (TM) laser distance meter.

In order to minimize impact on the fauna and avoid killing, we monitored the fauna using three sheets of corrugated cardboard, which were glued together using a starch-based glue to form single sheets of $15 \mathrm{~cm}$ height $\mathrm{x} 30 \mathrm{~cm}$ length. The presence of three sheets creates a thicker and longer lasting surface, otherwise, the high humidity of the cave would flake it quickly. The corrugated side was then placed on the ground (Fig. 2c). According to Caruso (1994), such a surface creates a microhabitat that attracts invertebrates, acting as a refuge, facilitating their count and eventual collection. We placed seventeen cardboard sheets within the cave.

The abundance of Armadillidium lagrecai under each cardboard was recorded at each sampling session. We also recorded the presence of Glomeris dionysii, Chthonius (Chthonius) multidentatus Beier 1963 (Arachnida: Pseudoscorpiones: Chthoniidae), Roncus siculus Beier 1963 (Arachnida: Pseudoscorpiones: Neobisiidae), Tychobythinus inopinatus Sabella, Costanzo and Nicolosi 2020 (Insecta: Coleoptera: Staphylinidae), and Plusiocampa (Plusiocampa) tinoamorei Sendra \& Nicolosi 2019 (Entognatha: Diplura: Campodeidae) (see Table S1 and Fig. S1).

Being the main climatic factors known to affect the distribution of subterranean species (Tobin et al., 2013; Mammola et al., 2015; Kozel et al., 2019), at each sampling session, we used an Indoor Air Quality Monitor Delta Ohm instrument to measure instant temperature and relative humidity at each cardboard site. The outside air temperature was provided by SIAS (Servizio Informativo Agrometeorologico Siciliano).

\section{Statistical analyses}

We performed all statistical analyses in $R(R$ Core Team, 2018). We explored the factors driving the spatial and temporal abundance of Armadillidium lagrecai within the cave using regression-type analyses (Zuur $\&$ Ieno, 2016). We calculated the standard deviation of temperature values during the whole sampling period and derived the subjacency (vertical distance from the surface) of each sampling point. We used abundance of individuals of A. lagrecai at each site as dependent variables. Given their low abundances, we could not fit regression models for the other species recorded in this study (Fig. S1).

We carried out data exploration following the protocol by Zuur et al. (2010). We evaluated the presence of outliers in the independent variables using Cleveland dotplots. We explored collinearity among 
the covariates using pairwise Pearson's $r$ correlations, setting the threshold for collinearity at $|r| \geq 0.7$. We explored non-linearity in the variable distributions and used coplots to evaluate the existence of potential interactions among covariates.

As a result of data exploration, we log-transformed the distance from the visitor pathway and squareroot-transformed the total number of visitors in the previous two weeks to homogenize their distribution and cope with a few outliers. Pairwise Pearson's correlations revealed that the temperature was collinear with relative humidity $(r=0.76)$, standard deviation of temperature $(r=-0.73)$, distance from entrance $(r=0.67)$ and subjacency $(r=0.62)$. The subjacency was also collinear with standard deviation of temperature $(r=-0.89)$, and distance from the entrance $(r=0.88)$. Therefore, we kept temperature as the only independent variable in the analysis.

During data exploration, we found a non-linear response of the abundance of $A$. lagrecai to the sampling week (cumulative counting), reflecting a seasonal variability in the abundance of the species. In light of this seasonal variability and the relative association of the sampling week with temperature, we decided to i) model the temporal distribution of $A$. lagrecai separately using a generalized additive model; and ii) to include the sampling week as a random term in the main regression model, in order to study the effect of microclimatic conditions and tourism on the abundance of $A$. lagrecai avoiding the confounding effect of seasonality.

With respect to i), we fitted the generalized additive model using the gam command in the $\mathrm{R}$ package gam (Hastie, 1991). The structure of the model (in $\mathrm{R}$ notation) was:

$$
\mathrm{y} \sim \mathrm{s}(\text { Sampling week) }
$$

where $\mathrm{y}=$ abundance of $A$. lagrecai and $\mathrm{s}=$ smooth term.

With respect to ii), we modelled the abundance of A. lagrecai with a Poisson generalized linear mixed model (Zuur et al., 2009). We fitted the model in $\mathrm{R}$ using the glmer command in the $\mathrm{R}$ package lme 4 (Bates et al., 2015). The structure of the initial model (in $\mathrm{R}$ notation) was:

$$
\begin{gathered}
\mathrm{y} \sim \text { Temperature }+ \text { Number of visitors + Distance } \\
\text { from the path }+(1 \mid \text { Sampling week })
\end{gathered}
$$

where $\mathrm{y}=$ abundance of $A$. lagrecai and (1| Sampling week) is a random term to deal with repeated observations and measurements at each sampling site.

Once we fitted the initial models, we performed model selection with the $\mathrm{R}$ package MuMIn (Bartón, 2016) to select a best performing model the minimized AIC and maximized Aikaike weight values (Zuur et al., 2009). We carried out model validation on the final model using the $\mathrm{R}$ package Performance (Lüdecke et al., 2020).

\section{RESULTS}

\section{Presence of visitors}

During the monitoring period, the cave was visited by 953 visitors with an average of 68 visitors/month. Visitors were more abundant in spring between April and June 2019, with a peak of 159 visitors in June. Visitors were also abundant in November 2019 and January 2020. In contrast, the number of visitors was low in August and December, with 29 and 32 visitors, respectively (Fig. 3).

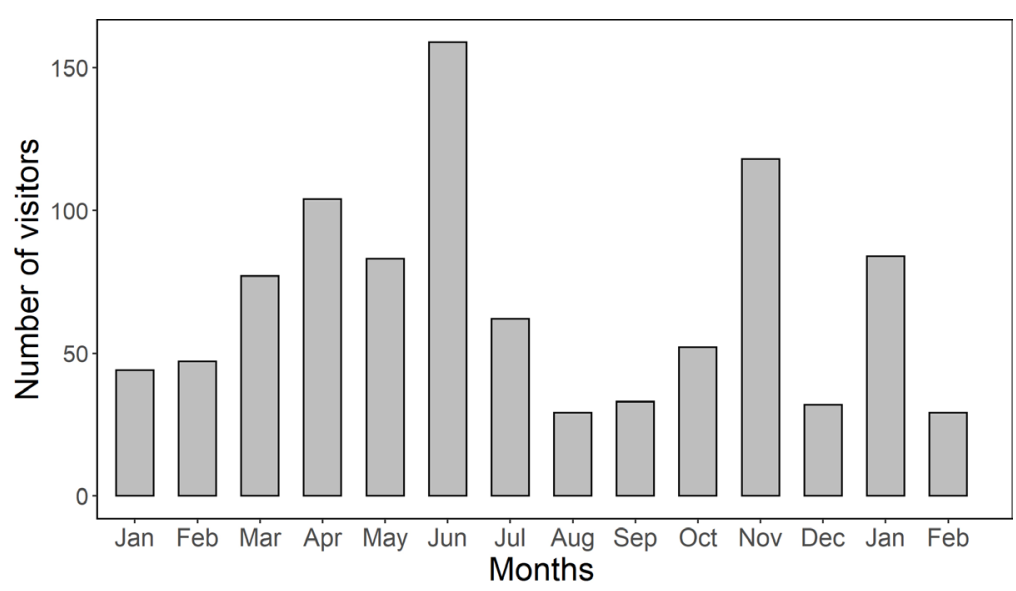

Fig. 3. Number of visitors/months during the monitoring activity.

\section{Cave temperature and relative humidity}

With regard to temperature, max-min ranges were attenuated with increasing distance from the cave entrance, and delayed compared to the values recorded outside the caves. The mean annual temperature values deep inside the cave (sites S13-S17) showed little variation over the year (mean $\pm \mathrm{SD}=18.4 \pm 0.29$ ). Conversely, temperature in the outermost sector (sites S1-S3) showed greater variability (mean $\pm \mathrm{SD}=14.8 \pm 2.2$ ). Here, temperature was relatively stable in summer, spring and autumn, while in winter temperature aligned with the outside temperature. The lowest temperatures were recorded in January $\left(12.7^{\circ} \mathrm{C}\right)$. The annual trend of the average temperature for each site is shown in Fig. 4.

Relative humidity was constantly close to saturation in the deeper part of the cave, with values ranging from 98 to $100 \%$ during the whole sampling period. In the entrance zone, the relative humidity measured was around $80 \%$ and showed greater variability (annual range of 20\%) (Fig. 5). 


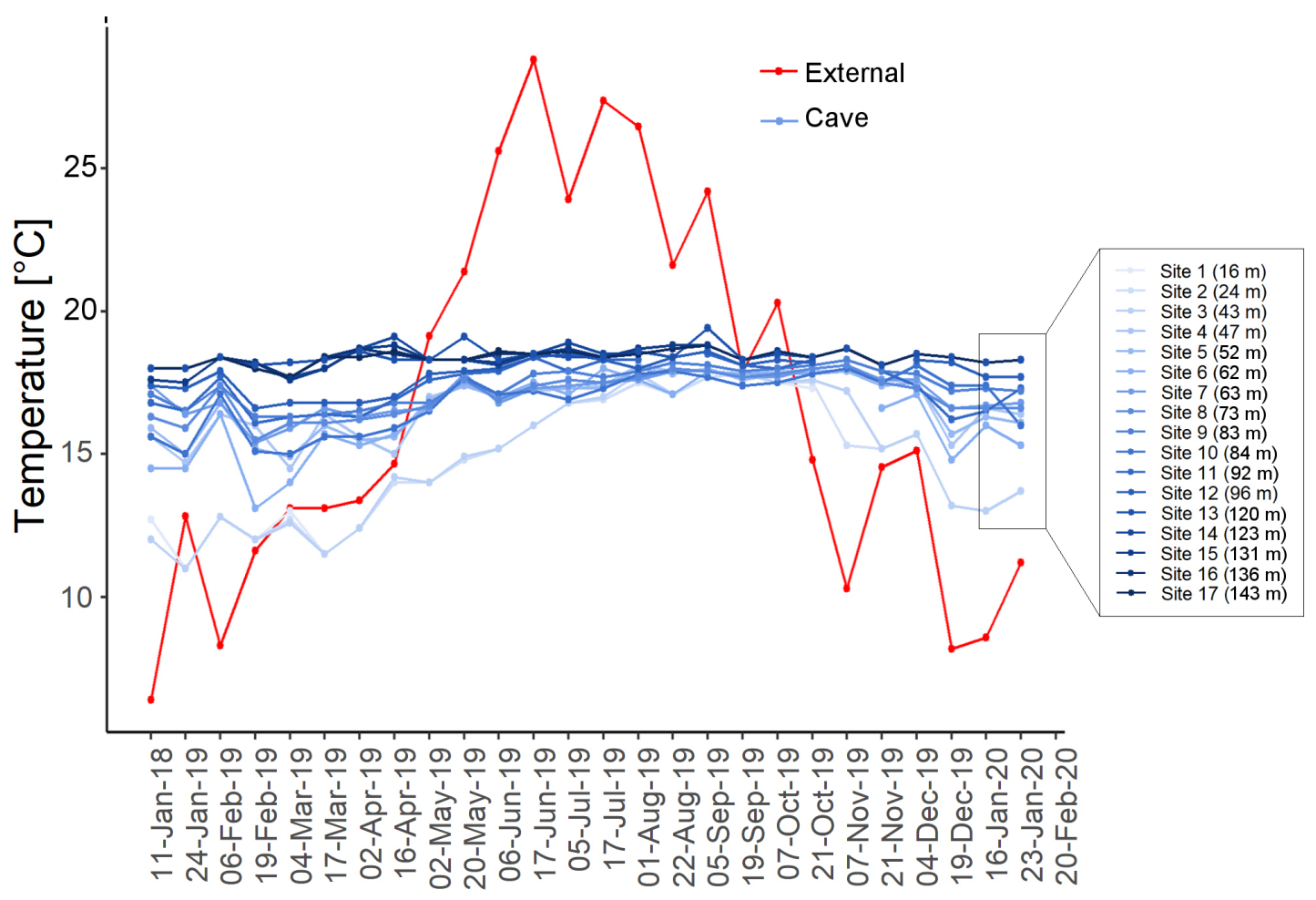

Fig. 4. Temperature of the Monello Cave. Annual trend of external temperature (red line) and temperatures inside the cave measured at each sampling site during the survey (blue lines). The shades of blues indicate the position of the sampling site relative to the cave entrance, from the outermost (lighter blues) to the innermost sites (darker blues).

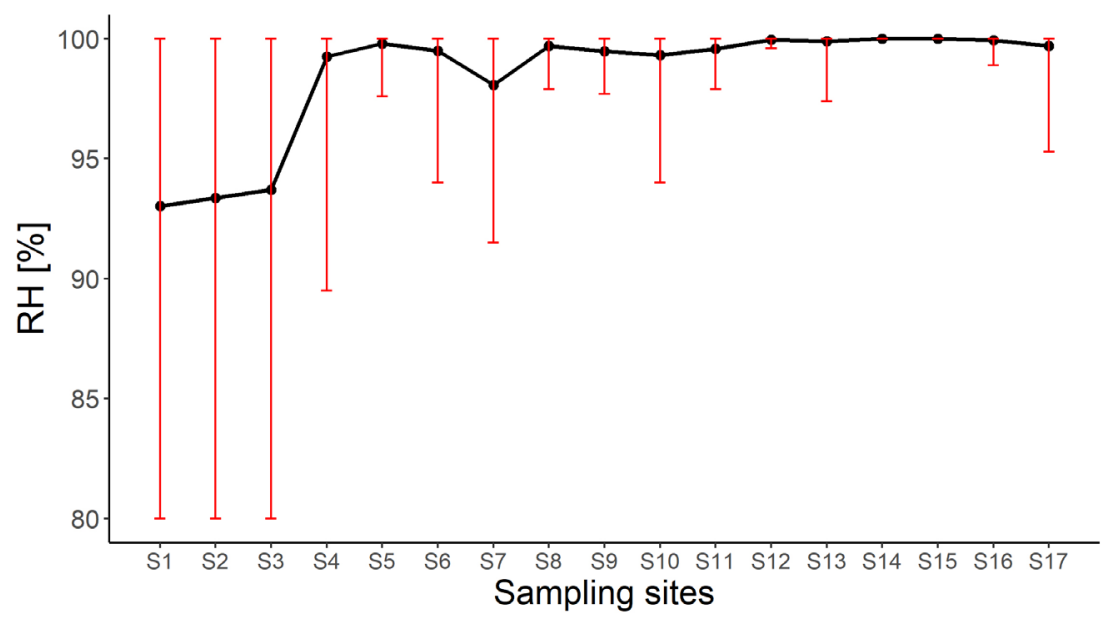

Fig. 5. Annual mean values of relative humidity with max-min ranges (red bars) for each sampling site.

\section{Temporal distribution of Armadillidium lagrecai}

The generalised additive model indicated that the abundance of Armadillidium lagrecai varied significantly throughout the sampling period (edf $\left.=5.14 ; x^{2}=46.15, \mathrm{p}<0.001\right)$, with a decrease from March to June and from November to January. In contrast, abundance increased in June and peaked in October (Fig. 6a).

\section{Factors affecting the abundance of Armadillidium lagrecai}

Results of model selection are shown in Table 1. The best performing model (Marginal $\mathrm{R}^{2}=0.77$; Random effect variance \pm s.d. $=0.11 \pm 0.33)$ included the temperature and the distance from the visitor path as a fixed term. According to the model, species abundance significantly increased with increasing temperature, with the maximum abundance around $18^{\circ} \mathrm{C}$ (Fig. 6b). Given that temperature was positively correlated with relative humidity ( $r=0.8)$, we recovered the same trend when we built the model by using the relative humidity instead of temperature (Fig. 6c), with Armadillidium lagrecai being more abundant in the sampling sites with relative humidity approaching or reaching saturation. None of the other factors had a significant influence on abundance, including the number of visitors and the distance from the tourist path. However, the latter was kept in the final model even though it was not significant based on the $z$-test $(\mathrm{p}=0.06)$.

It is worth noting that the final model was slightly overdispersed (dispersion ratio $=2.1$; Pearson's $\left.x^{2}=902.612 ; \mathrm{p}<0.001\right)$. However, in light of the model validation (Fig. S2) and given that overdispersion ratio was rather low, we determined that the Poisson distribution was adequate and we did not switch to a quasi-Poisson or negative binomial distribution. 


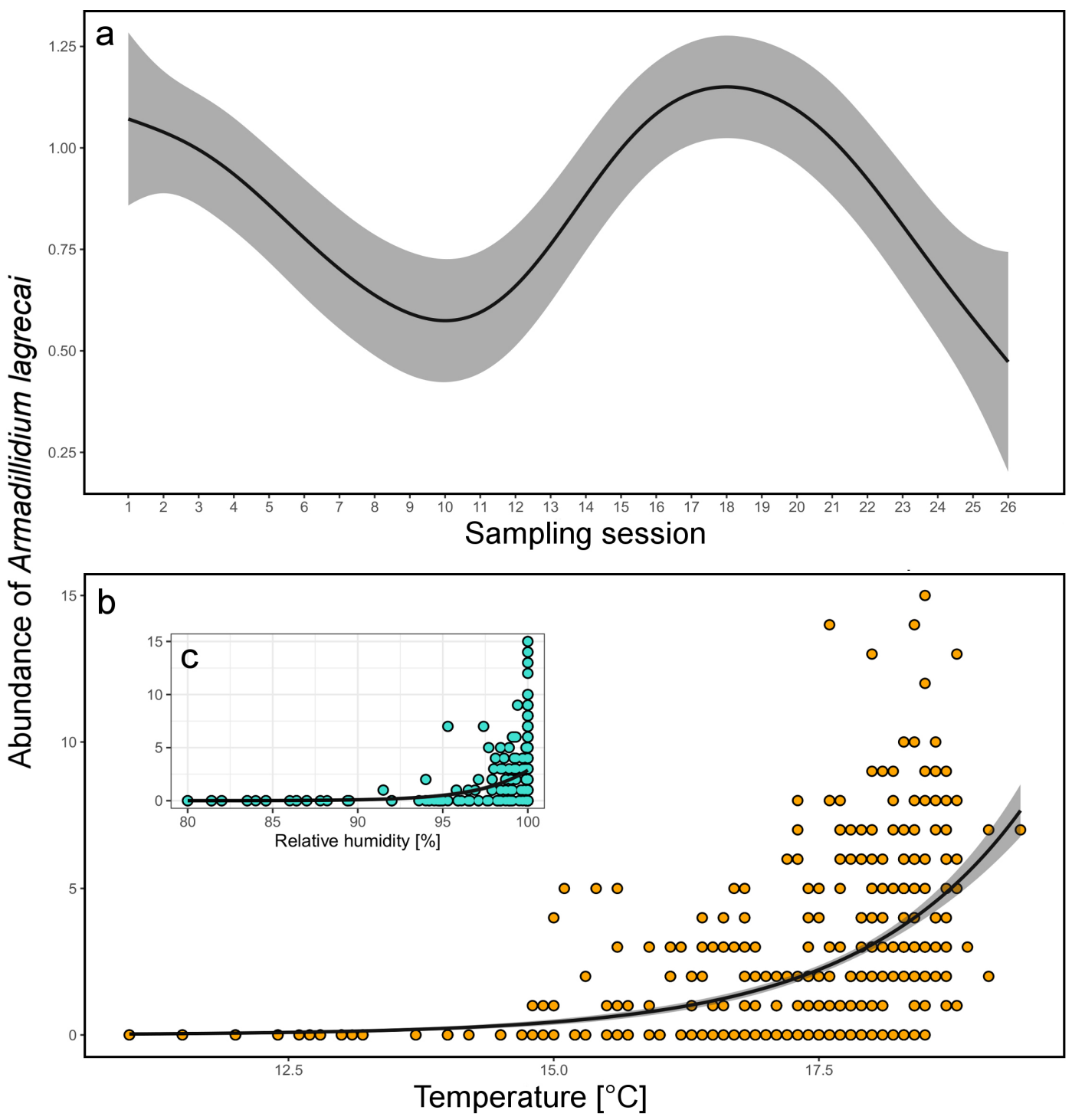

Fig. 6. a) Abundance trends of Armadillidium lagrecai in the Monello Cave. Generalized additive model analysispredicted values (black line) and 95\% confidence intervals (grey area) of abundance over time (smoother); b) Effect of temperature on the abundance according to a generalized linear mixed model. The inset graph (c) shows the trend obtained using relative humidity instead of temperature as explanatory variables in the model.

Table 1. Results of model selection and estimated regression parameters. Estimated regression parameters (Estimated $\beta \pm S$.E.) for the fixed term are given only for the selected model. $\mathrm{AIC}=$ Aikaike Information Criterion; $\triangle \mathrm{AIC}=(\mathrm{AIC}$ of the model $-\mathrm{AIC}$ of the best model); $\mathrm{df}=\mathrm{Degrees}$ of freedom; wi = Aikaike weights.

\begin{tabular}{|c|c|c|c|c|c|c|c|}
\hline Model structure & Variables & Estimated $\beta \pm$ S.E. & p-value & d.f. & AIC & $\Delta \mathbf{A I C}$ & $\mathbf{w}_{\mathbf{i}}$ \\
\hline \multirow{3}{*}{$\begin{array}{l}\mathrm{y} \sim \text { Temperature }+ \\
\text { Distance from the path }+ \\
\text { (1| Sampling week) }\end{array}$} & Intercept & $-12.32 \pm 0.77$ & - & \multirow{3}{*}{4} & \multirow{3}{*}{1776.56} & \multirow{3}{*}{0.00} & \multirow{3}{*}{0.67} \\
\hline & Temperature & $0.74 \pm 0.04$ & $<0.001$ & & & & \\
\hline & $\begin{array}{c}\text { Distance from the } \\
\text { path (log-transformed) }\end{array}$ & $0.05 \pm 0.03$ & 0.06 & & & & \\
\hline $\begin{array}{l}\text { y } \sim \text { Temperature }+ \\
\text { (1| Sampling week) }\end{array}$ & & - & - & 3 & 1777.95 & 1.39 & 0.33 \\
\hline $\begin{array}{l}\mathrm{y} \sim \text { Temperature + Number } \\
\text { of visitors + Distance from } \\
\text { the path + (1| Sampling } \\
\text { week }\end{array}$ & & - & - & 6 & 2239.73 & 463.16 & 0.00 \\
\hline
\end{tabular}

\section{DISCUSSION}

The opening of a cave to tourism activities impacts the cave ecosystem in several ways. The presence of visitors can lead the environmental alterations in terms of heat, airflow, humidity, and moisture (De Freitas, 2010), which potentially affects the resident fauna. Despite subterranean arthropod diversity in show caves could be high (see Culver $\&$ Sket, 2002), investigations aiming at unravelling the effect of tourism on cave arthropods remain scarce (e.g., Casale et al., 2008; Barciov et al., 2010; Fong, 2011; Isaia et al., 2011; Pellegrini \& Ferreira, 2012; Faille et al., 2014; Pacheco et al., 2020).

By monitoring tourist access, it is possible to assess their effect on cave climatic stability, and eventually modify management strategies (Faille et al., 2014). For instance, monitoring activities should be carried out to evaluate the impact of human visitors on subterranean fauna and microclimate, especially if the cave falls within protected areas. 
Although caves are stable environments, they exhibit seasonal changes in their microclimate which may modify the spatial and temporal distribution of subterranean species (Barr \& Kuene, 1971; Peck, 1976; Howarth, 1980). These microclimate fluctuations are usually greater near the entrance, where the cave is most affected by external conditions, and drastically decrease in the deep areas where air temperatures remain stable, even when the external air temperature changes (Badino, 2010). Consequently, as in the Monello Cave, deep cave sectors emerge as optimal habitat for specialized subterranean fauna (Tobin et al., 2013; Mammola et al., 2015).

Based on the results of regression analysis, temperature and relative humidity seems to be more important than direct human impact in driving the distribution of Armadillidium lagrecai in the Monello Cave. Our data suggest that microclimate influences the spatial distribution of $A$. lagrecai, confirming its preference for the warmest and most stable cave sections, as well as an apparent seasonality effect on abundance variation which is possibly related to reproduction (Caruso, 1994).

The high correlation between temperature and relative humidity suggests the two factors play equally important roles in determining $A$. lagrecai abundance. The species showed a preference for areas of the cave where relative humidity approached or reached saturation (Fig. 6c). Relative humidity is considered to be one of the most important ecological limiting factors in the subterranean domain (Howarth, 1980; 1983), since even small variations can double the evaporation rate (Buecher, 1999) and have direct consequences on the resident fauna (Howarth, 1980). For example, subterranean woodlice possess cuticles with disproportionately thinner and more numerous endocuticular lamellae compared to their surface counterparts; the mechanisms preventing the evaporative loss of water are therefore reduced (Vittori et al., 2017).

Armadillium lagrecai abundance increased in summer (July-September) when temperature increased within the cave, and gradually decreased during the coldest months (October-January). This corroborates findings from Caruso (1994), who described a reproductive peak in May for the A. lagrecai when the warm season begins and cave temperatures gradually rise.

Armadillidium lagrecai demonstrated a clear preference for the innermost sampling sites of the cave $(>96 \mathrm{~m})$ where microclimate fluctuations were minimal. Moreover, considering the high correlation between the subjacency and both temperature and the distance from the cave entrance, we can infer that the abundance of $A$. lagrecai increased in the deeper zones with greater subjacency $(>20 \mathrm{~m})$. However, it was also in these innermost sections of the cave that we counted a lower number of specimens in the coldest months. This would suggest migrations toward the deeper voids and fissures of the cave, which according to Badino (2010) are characterized by even greater stability in terms of temperature fluctuation.
The distance from the visitor path was the only factor besides temperature that we kept in the analysis; however, its effect was not found to be statistically significant.

In accordance with previous studies (Faille et al., 2014; Pacheco et al., 2020), our analysis has not detected a strong direct effect of the presence of visitors on the abundance of our model species. In other words, with a moderate regime of 68 visitors per month, the current management of the Monello Cave does not seem to harm this subterranean species. The number of visitors present during the sampling activities, as well as the rigorous path delimitation, appears to minimize human disturbance. However, given the effect that a larger number of visitors may have on the cave microclimate, any departure from the current visitors regime we observed should be carefully assessed for the proper management of the cave.

\section{CONCLUSIONS}

The study investigated the factors affecting the microhabitat selection of Armadillidium lagrecai.

Under current management, it appears that the existing visitors regime in the Monello Cave has no effect on the abundance and distribution of A. lagrecai. Our data suggested that the species preferably select the areas of the cave where the microclimate factors were mostly constant during the sampling activities. The observed abundance fluctuations were determined by the microclimatic regime that occurs naturally inside the cave rather than by any disturbances caused by visitors.

However, any increase in visitor trampling could potentially cause the death of cave arthropods crossing the path or hiding under stones. Considering the moderate size of the cave, the number of visitors along the route should therefore continue to be scheduled, also limiting the permanence time in the "Sala Grande", which correspond to the most microclimatically suitable area for the species.

Finally, it cannot be excluded that greater number of visitors could alter the cave microclimate in terms of temperature and humidity (Baker \& Genty, 1998; Dominguez-Villar et al., 2010). Considering the high sensitivity of $A$. lagrecai to microclimate variations, and the fact that Monello Cave is one of the richest areas of troglobitic species in Sicily while being relatively small in size, the presence of visitors should continue to be accurately monitored with microclimatic surveys and visitor limitations maintained.

\section{ACKNOWLEDGEMENTS}

We are thankful to Jenny Liu for proofreading our English. This study was funded by Assessorato Regionale del Territorio e dell'Ambiente of the Regione Siciliana [Management Funds of Strict Nature Reserve "Grotta Monello" 2018, 2019]; SM is supported by the European Union's Horizon 2020 research and innovation programme under grant agreement No. 882221. The research is included 
in the investigations conducted in the frame of "SHOWCAVE: a multidisciplinary research project to study, classify and mitigate the environmental impact in tourist caves", funded by Ministero Ministero dell'Istruzione and Ministero dell'Università e della Ricerca [PRIN: Progetti di ricerca di rilevante interesse nazionale 2017 - Prot. 2017HTXT2R].

Authorship statement: GN and MI set the lines of enquiry, designed the study and led the writing of the paper. GN wrote the first draft of the paper and prepared figures and tables. GN, SC, and GS set the sampling activities and collected the data. SM and GN analyzed the data. All authors reviewed the first draft of the paper and provided important improvements to the original text. This study is framed into a scientific investigation conceived by $\mathrm{RC}, \mathrm{SC}$, and $\mathrm{GS}$ aimed at evaluating the impact of visitors on the Monello Cave.

\section{REFERENCES}

Badino, G., 2010. Underground meteorology. What's the weather underground? Acta Carsologica, 39(3), 427448. https://doi.org/10.3986/ac.v39i3.74

Baker, A., Genty, D., 1998. Environmental pressures on conserving cave speleothems: effects of changing surface land use and increased cave tourism. Journal of Environmental Management, 53(2), 165-175. https://doi.org/10.1006/jema.1998.0208

Baquedano Estévez, C., Moreno-Merino, L., de la Losa Román, A., Durán Valsero, J.J., 2019. The lampenflora in show caves and its treatment: an emerging ecological problem. International Journal of Speleology, 48(3), 4, 249-277.

https://doi.org/10.5038/1827-806X.48.3.2263

Barciová, T., Kovác, L., Miklisová, D., 2010. Impact of tourism upon structure and diversity of Collembola assemblages (Hexapoda) - a case study of the Gombasecká Cave, Slovak Karst (Slovakia). Acta carsologica slovaca, 48, 271-283.

Barr, T.C., Kuehne, R.A., 1971. Ecological studies in Mammoth Cave ecosystems of Kentucky. II. The ecosystem. Annales de Spéléologie, 26, 47-96.

Bartón, K., 2016. R-package 'MuMIn', Model selection and model averaging based on information criteria (AICc and alike). (https://cran.r-project.org/web/packages/MuMIn/ index.html)

Bates, D., Mächler, M., Bolker, B., Walker, S., 2015. lme4: Linear mixed-effects models using Eigen and S4. $\mathrm{R}$ package version 1.1-8. (http:// cran.r-project.org/package=lme4)

Bernabò, P., Latella, L., Jousson, O., Lencioni, V., 2011. Cold stenothermal cave-dwelling beetles do have an HSP70 heat shock response. Journal of Thermal Biology, 36, 206-208.

https://doi.org/10.1016/j.jtherbio.2011.03.002

Buecher, B., 1999. Microclimate study of Kartchner Caverns, Arizona. Journal of Cave and Karst Studies, 61(2), 108-120.

Caruso, D., 1994. La fauna della grotta Monello. Atti e Memorie dell'Ente Fauna Siciliana, 2, 87-21.

Casale, A., Grafitti, G., Lana, E., Marcia, P., Molinu, A., Mucedda, M., Onnis, C., Stoch, F., 2008. La Grotta del Bue Marino: cinquanta anni di ricerche biospeleologiche in Sardegna. Memorie dell'Istituto Italiano di Speleologia, s. II, 28, 59-71.
Castello, M., 2014. Species diversity of bryophytes and ferns of Lampenflora in Grotta Gigante (NE-Italy). Acta Carsologica, 43(1), 185-193. https://doi.org/10.3986/ac.v43i1.576

Chelius, M.K., Beresford, G., Howard Horton, H., Quirk, M., Selby, G., Simpson, R.T., Horrocks, R., Moore, J.C., 2009. Impacts of alterations of organic inputs on the bacterial community within the sediments of wind Cave, South Dakota, USA. International Journal of Speleology, 38, 1-10.

https://doi.org/10.5038/1827-806X.38.1.1

Cigna, A.A., 1993. Environmental management of tourist caves. Environmental Geology, 21, 173-180.

https://doi.org/10.1007/BF00775302

Cigna, A.A., 2004. Climate of caves. In: Gunn, J. (Ed.), Encyclopedia of caves and karst science. Taylor and Francis, London, p. 467-475.

Cigna, A.A., 2016. Tourism and show caves. Zeitschrift für Geomorphologie, 60, 217-233.

https://doi.org/10.1127/zfg_suppl/2016/00305

Culver, D.C., 2005. Life history evolution. In: Culver, D.C., White, W.B. (Eds), Encyclopedia of caves. Elsevier. Amsterdam, The Netherlands, p. 346-349.

Culver, D.C., Pipan, T., 2010. Climate, abiotic factors, and the evolution of subterranean life. Acta Carsologica, 39(3), 39-577. https://doi.org/10.3986/ac.v39i3.85

Culver, D., Pipan, T., 2019. The biology of caves and other subterranean habitats. Oxford University Press, Oxford, $336 \mathrm{p}$.

https://doi.org/10.1093/oso/9780198820765.001.0001

Culver, D.C., Sket, B., 2002. Biological monitoring in caves. Acta Carsologica, 31, 55-64.

https://doi.org/10.3986/ac.v31i1.403

De Freitas, C.R., 2010. The role and importance of cave microclimate in the sustainable use and management of show caves. Acta Carsologica, 39, 477-489.

https://doi.org/10.3986/ac.v39i3.77

Dominguez-Villar, D., Fairchild, I. J., Carraasco, R. M., Pedraza, J., Baker, A., 2010. The effect of visitors in a touristic cave and the resulting constraints on natural thermal conditions for palaeoclimate studies (Eagle Cave, central Spain). Acta Carsologica, 39(3), 491-502. https://doi.org/10.3986/ac.v39i3.78

Eberhard, S., 2001. Cave fauna monitoring and management at Ida Bay, Tasmania. Records of the Western Australia Museum Supplement, 64, 97-104. https://doi.org/10.18195/issn.0313-122x.64.2001. 097-104

Faille, A., Bourdeau, C., Deharveng, L., 2014. Weak impact of tourism activities on biodiversity in a subterranean hotspot of endemism and its implications for the conservation of cave fauna. Insect Conservation and Diversity, 8, 205-215. https://doi.org/10.1111/icad.12097

Falasco, E., Ector, L., Isaia, M., Wetzel, C.E., Hoffmann, L., Bona, F., 2014. Diatom flora in subterranean ecosystems: a review. International Journal of Speleology, 43, 231-251.

https://doi.org/10.5038/1827-806X.43.3.1

Fernandez-Cortes, A., Calaforra, J.M., Sanchez-Martos F., 2006. Spatiotemporal analysis of air microclimatic conditions a tool for show cave environmental management (Cueva del Agua Spain). Atmospheric Environment, 40, 7378-7394.

https://doi.org/10.1016/j.atmosenv.2006.06.045

Fong, D.W., 2011. Management of Subterranean Fauna in Karst. In: van Beynen, P. (Ed.), Karst management. Springer, Dordrecht, p. 201-224.

https://doi.org/10.1007/978-94-007-1207-2_9 
Ghisetti, F., Vezzani, L., 1980. The structural features of the Iblean plateau and of the Mount Judicaarea (southeastern Sicily): A microtectonic contribution to the deformational history of the Calabrian Arc. Bolletino Società Geologica Italiana, 99, 57-102.

Hastie, T.J., 1991. Generalized additive models. In: Chambers, J.M., Hastie, T.J. (Eds.), Statistical models in S, Wadsworth \& Brooks/Cole, Pacific Grove, CA, p. 249-307.

Howarth, F.G., 1980. The zoogeography of specialized cave animals: a bioclimatic model. Evolution, 34, 394406. https://doi.org/10.2307/2407402

Howarth, F.G., 1983. Ecology of cave arthropods. Annual Review of Entomology, 28, 365-389.

https://doi.org/10.1146/annurev.en.28.010183.002053

Howarth, F.G., 1993. High-stress subterranean habitats and evolutionary change in cave-inhabiting arthropods. American Naturalist, 142 (Supplement), 65-77. https://doi.org/10.1086/285523

Huppert, G., Burri, E., Forti, P., Cigna, A., 1993. Effects of tourist development on caves and karst. In: Williams, P.W. (Ed.), Karst terrains, environmental changes, human impact. Catena Supplement 25, 251-268.

Isaia, M., Giachino, P.M., Sapino, E., Casale, A., Badino, G., 2011. Conservation value of artificial subterranean systems: a case study in an abandoned mine in Italy. Journal for Nature Conservation, 19, 24-33. https://doi.org/10.1016/j.jnc.2010.04.002

Juberthie, C., Delay, B., 2000. The diversity of the karstic and pseudokarstic hypogean habitats in the world. In: Wilkens, H., Culver, D.C., Humphreys, E.F. (Eds.), Subterranean ecosystems. Elsevier, Amsterdam, 17-39.

Kozel, P., Pipan, T., Mammola, S., Culver, D. C., Novak, T., 2019. Distributional dynamics of a specialized subterranean community oppose the classical understanding of the preferred subterranean habitats. Invertebrate Biology, 138(3), e12254. https://doi.org/10.1111/ivb.12254

Krajick, K., 2001. Cave biologists unearth buried treasure. Science, 293, 2378-2381.

https://doi.org/10.1126/science.293.5539.2378

Lüdecke, D., Makowski, D., Waggoner, P., 2020. Assessment of regression models performance. $\mathrm{R}$ package version 0.4.4.

(https://CRAN.R-project.org/package=performance)

Mammola, S., 2019. Finding answers in the dark: Caves as models in ecology fifty years after Poulson and White. Ecography, 42, 1331-1351.

https://doi.org/10.1111/ecog.03905

Mammola, S., Piano, E., Giachino, P.M., Isaia, M., 2015. Seasonal dynamics and micro-climatic preference of two Alpine endemic hypogean beetles. International Journal of Speleology, 44, 239-249. https://doi.org/10.5038/1827-806X.44.3.3

Mammola, S., Di Piazza, S., Ziotti, M., Badino, G., Isaia, M., 2017. Human-induced alterations of the mycobiota in an Alpine show cave (Italy, SW-Alps). Acta Carsologica, 46, 111-123. https://doi.org/10.3986/ac.v46i1.2531

Mammola, S., Cardoso, P., Culver, D.C., Deharveng, L., Ferreira, R.L., Fišer, C., Galassi D.M.P., Griebler, C., Halse, S., Humphreys, W.F., Isaia, M., Malard, F., Martinez, A., Moldovan, O.T., Niemiller, M.L., Pavlek, M., Reboleira, A.S.P.S., Souza-Silva, M., Teeling, E.C., Wynne, J.J., Zagmajster, M., 2019a. Scientists'warning on the conservation of subterranean ecosystems. BioScience, 69(8), 641-650.

https://doi.org/10.1093/biosci/biz064
Mammola, S., Piano, E., Malard, F., Vernon, P., Isaia, M., 2019b. Extending Janzen's hypothesis to temperate regions: a test using subterranean ecosystems. Functional Ecology, 33(9), 1638-1650.

https://doi.org/10.1111/1365-2435.13382

Mammola, S., Amorim, I.R., Bichuette, M.E., Borges, P.A.V., Cheeptham, N., Cooper, S.J.B., Culver, D.C., Deharveng, L., Eme, D., Ferreira, R.L., Fišer, C., Fišer, Ž., Fong, D.W., Griebler, C., Jeffery, W.R., Jugovic, J., Kowalko, J.E., Lilley, T.M., Malard, F., Manenti, R., Martínez, A., Meierhofer, M.B., Niemiller, M.L., Northup, D.E., Pellegrini, T.G., Pipan, T., Protas, M., Reboleira, A.S.P.S., Venarsky, M.P., Wynne, J.J., Zagmajster, M., Cardoso, P., 2020. Fundamental research questions in subterranean biology. Biological Reviews, brv. 12642 .

https://doi.org/10.1111/brv.12642

Mulec, J., 2014. Human impact on underground cultural and natural heritage sites, biological parameters of monitoring and remediation actions for insensitive surfaces: Case of Slovenian show caves. Journal for Nature Conservation, 22(2), 132-141.

Mulec, J., Kosi, G., Vrhovšek, D., 2008. Characterization of cave aerophytic algal communities and effects of irradiance levels on production of pigments. Journal of Cave and Karst Studies, 70(1), 3-12.

Mulec, J., Kosi, G., 2009. Lampenflora algae and methods of growth control. Journal of Cave and Karst Studies, $71,109-115$.

Nicolosi, G., Amore, E., Costanzo, S., Sendra A., Cirrincione, R., Signorello, G., Sabella, G., 2019. Subterranean fauna in two protected caves in the Hyblean area (Syracuse, Sicily). ARPHA Conference Abstracts 2: e46626.

https://doi.org/10.3897/aca.2.e46626

Novak, T., Šajna, N., Antolinc, E., Lipovšek Delakorda, S., Devetak, D., Janžekovič, F., 2014. Cold tolerance in terrestrial invertebrates inhabiting subterranean habitats. International Journal of Speleology, 43(3), 265-272.

https://doi.org/10.5038/1827-806X.43.3.3

Pacheco, G.S.M., de Oliveira, M.P.A., Cano, E., Souza Silva, M., Ferreira, R.L., 2020. Tourism effects on the subterranean fauna in a Central American cave. Insect Conservation and Diversity (Advanced online publication). https://doi.org/10.1111/icad.12451.

Pallarés, S, Colado, R, Pérez-Fernández, T, Wesener, T, Ribera, I, Sánchez-Fernández, D., 2019. Heat tolerance and acclimation capacity in subterranean arthropods living under common and stable thermal conditions. Ecology and Evolution, 9, 13731-13739. https://doi.org/10.1002/ece3.5782

Pallarés, S., Colado, R., Botella-Cruz, M., Montes, A., Balart-García, P., Bilton, D. T., Millán A., Ribera I., Sánchez-Fernández, D., 2020. Loss of heat acclimation capacity could leave subterranean specialists highly sensitive to climate change. Animal Conservation. (Advanced online publication).

https://doi.org/10.1111/icad.12455

Peck, S.B., 1976. The effects of cave entrances on the distribution of cave inhabiting terrestrial arthropods. International Journal of Speleology, 8, 309-321. https://doi.org/10.5038/1827-806X.8.4.1

Pedley H.M., 1981. Sedimentology and palaeoenvironment of the southeast Sicilian Tertiary platform carbonates. Sedimentary Geology, 28, 273-291. https://doi.org/10.1016/0037-0738(81)90050-6

Pellegrini, T.G., Ferreira, R.L., 2012. Management in a neotropical show cave: planning for invertebrates 
conservation. International Journal of Speleology, 41(2), 359-366.

https://doi.org/10.5038/1827-806X.41.2.19

Pfendler, S., Karimi, B., Maron, P.A., Ciadamidaro, L., Valot, B., Bousta, F, Alaoui-Sosse, L., Alaoui-Sosse, B., Aleya, L., 2018. Biofilm biodiversity in French and Swiss show caves using the metabarcoding approach: first data. Science of the Total Environment, 615, 1207-1217. https://doi.org/10.1016/j.scitotenv.2017.10.054

Piano, E., Bona, F., Falasco, E., La Morgia, V., Badino, G., Isaia, M., 2015. Environmental drivers of phototrophic biofilms in an Alpine show cave (SW-Italian Alps). Science of the Total Environment, 536, 1007-1018. https://doi.org/10.1016/j.scitotenv.2015.05.089

Poulson, T.L., White W.B., 1969. The cave environment. Science, 165, 971-981. https://doi.org/10.1126/science.165.3897.971

R Core Team, 2018. R: A Language and Environment for Statistical Computing. R Foundation for Statistical Computing, Vienna, Austria.

https://www.R-project.org [accessed: March 16, 2020].

Rizzo, V., Sánchez-Fernández, D., Fresneda, J., Cieslak, A., Ribera, I., 2015. Lack of evolutionary adjustment to ambient temperature in highly specialized cave beetles. BMC Evolutionary Biology, 15, 10.

https://doi.org/10.1186/s12862-015-0288-2

Romero, A., 2009. Cave biology. Cambridge University Press, Cambridge, 306 p.

https://doi.org/10.1017/CBO9780511596841

Ruggieri, R., Amore, C., 2000. Elementi geostrutturali e paleomorfologici del sistema carsico Grotta Monello (Sicilia sudorientale). Speleologia Iblea, 8, 75-81.

Sabella, G., Costanzo, S., Nicolosi, G., 2020. A new troglobitic Tychobythinus from Sicily (Coleoptera, Staphylinidae, Pselaphinae). Zootaxa, 4779(2), 273281. https://doi.org/10.11646/zootaxa.4779.2.8

Sendra, A., Nicolosi, G., Amore, E., 2019. Subterranean Campodeidae fauna from Sicily Island (Diplura): its biogeographical interest with the description of a new species of Plusiocampa. Zootaxa, 4679(2), 297-317. https://doi.org/10.11646/zootaxa.4679.2.5
Singh, T., Bhat, M.M., Khan, M.A., 2009. Insect Adaptations to Changing Environments -Temperature and Humidity. International Journal of Industrial Entomology, 19(1), 155-164.

Slaney, D.P., Weinstein, P., 1997. Conservation of cave fauna: more than just bats. Memoirs of Museum Victoria, 56, 591-596.

https://doi.org/10.24199/j.mmv.1997.56.55

Spate, A., Hamilton-Smith, E., 1991. Cavers impacts - some theoretical and applied considerations. Proceedings of the 9th Australasian Conference on Cave and Karst Management, Margaret River, Western Australia, p. 20-30.

Tobin, B.W., Hutchins, B.T., Schwartz, B.F., 2013. Spatial and temporal changes in invertebrate assemblage structure from the entrance to deep-cave zone of a temperate marble cave. International Journal of Speleology, 42, 203-214.

https://doi.org/10.5038/1827-806X.42.3.4

van Beynen, P., Townsend, K.A., 2005. Disturbance index for karst environments. Environmental Management, 36, 101-116.

https://doi.org/10.1007/s00267-004-0265-9.

Vittori, M., Tušek-Žnidarič, M., Štrus J., 2017. Exoskeletal cuticle of cavernicolous and epigean terrestrial isopods: a review and perspectives. Arthropod Structure and Development, 46, 96-107. https://doi.org/10.1016/j.asd.2016.08.002

Zuur, A.F., Ieno, E.N., Walker, N.J., Savaliev, A.A., Smith, G.M., 2009. Mixed effect models and extensions in ecology with R. Springer, Berlin, 574 p. https://doi.org/10.1007/978-0-387-87458-6

Zuur, A.F., Ieno, E.N., Elphick, S.C., 2010. A protocol for data exploration to avoid common statistical problem. Methods in Ecology and Evolution, 1, 3-14. https://doi.org/10.1111/j.2041-210X.2009.00001.x

Zuur, A.F., Ieno, E.N., 2016. A protocol for conducting and presenting results of regression-type analyses. Methods in Ecology and Evolution, 7(6), 636-645. https://doi.org/10.1111/2041-210X.12577 